\title{
Pentecostal Praise and Worship as a Mode of Theology
}

\author{
Martina Prosén
}

It is Wednesday evening March 12 th 2014 and about twenty people are gathered in CITAM Woodley ${ }^{1}$ for what is called Power House. ${ }^{2}$ Before long another hundred have joined this weekly prayer gathering for the church. As with all services in branches affiliated with Christ is the Answer Ministries, it starts with about half an hour of praise and worship. Some songs are sung in Swahili but, apart from that, English is the common language in this urban, middle-class, Pentecostal church situated in Nairobi, Kenya. The worship team leads the congregation in a well-known worship song sung in charismatic churches worldwide:

You deserve the glory and the honor

Lord, we lift our hands in worship

As we lift your Holy name. ${ }^{3}$

People raise their hands, encouraged by the song, and some bow their knees before God. This is a time of worship, of adoration, of surrendering to God who is Holy. Soon there will be prayers for specific themes but right now it is time for focusing one's attention on God alone and reminding oneself of who He is. The worship leader erupts into short spoken prayers in between the stanzas, repeating and reinforcing the message of the song: "We worship your name, oh Lord." "You deserve all the glory, all the honor." "Hallelujah! There is no one else like you." Then the same song continues in Swahili as the service proceeds. ${ }^{4}$

1 Citam Woodley is an abbreviation of the Woodley branch of the Christ is the Answer Ministries, a Pentecostal church consisting of over twenty semi-autonomous branches. See below for a more detailed description.

2 This article was first presented as a paper in the international conference "African Lived Christianity - Faith, Ritual and Power" at Lund University, Sweden, March 2016.

3 Worship set, Woodley 20140312 Power House. Song composed originally in Swedish by Eva Hellmark (Vivill ge dig äran) and English translation by Terry MacAlmon, http://www.musicnotes.com/sheetmusic/mtd.asp?ppn=MNo123554 (accessed 2017-02-06).

4 Observation guide, Woodley Power House 20140312. Sound recording, Woodley 20140312 Power House. Field notes, Woodley Power House 6pm 20140312. All field notes, observation 
Long before my fieldwork in Nairobi, Kenya in 2013-2014, ${ }^{5}$ I started to ponder the relationship between Pentecostal praise and worship practices and Pentecostal theology. Inspired by such theologians as Robert Schreiter, ${ }^{6}$ Steven Land, ${ }^{7}$ and Ulrik Josefsson ${ }^{8}$ I had found it important to search for theology not only in academic texts but also in (for theologians) unconventional sources such as communal activities, songs, testimonies, and Christian journals. With the help of Daniel Albrecht ${ }^{9}$ and others, my eyes were opened to the ritual qualities of praise and worship and the central role it has in contemporary charismatic liturgy. I soon started to ask theological and theoretical questions when listening to worship songs or participating in church services in my home church and elsewhere. In heading for the field in Nairobi, my goal was to search for the theology that is expressed in worship as well as the theology that motivates worship. In hearing songs like the one quoted above ("You deserve the glory"), I was thinking about what the song says about God and his character, or what it says about the cosmos and the place of human beings within it. Increasingly, however, I came to think of the songs as not merely expressing theology (as if theology was something already given and static), but as also crafting theology, constantly re-creating and molding the very faith that they express. I am now convinced that this process takes place not just when the song is composed, but also as the song is sung in a liturgical context. To me, congregational singing is thus a creative activity that both shapes and conveys theological knowledge. ${ }^{10}$

guides, worship sets, sound recordings, interviews and lyrics referred to in this article are in the author's possession. In the last part of the chapter I describe my fieldwork method and these different categories of collected data.

The four months of fieldwork in Nairobi were carried out as part of my PhD project, a qualitative study of two Charismatic churches (CitAm Woodley and Mavuno Church), focusing on theological and ritual aspects of praise and worship. The idea is to combine ethnographic research methods with theological analysis to create a nuanced and rich picture of how praise and worship function within the communal life of these churches. Due to space constrains I have chosen to delimit the discussion in this chapter to CITAM Woodley.

6 Robert Schreiter, Constructing Local Theologies (Maryknoll: Orbis Books, 1985).

7 Steven Jack Land, Pentecostal Spirituality: A Passion for the Kingdom (Cleveland: CPT Press, 2010).

8 Ulrik Josefsson, Liv och över nog: Den tidiga pingströrelsens spiritualitet, (Skellefteå: Artos \& Norma Bokförlag, 2005).

9 Daniel Albrecht, Rites of the Spirit: A ritual approach to Pentecostal/Charismatic Spirituality (Sheffield: Sheffield Academic Press, 1999).

10 Compare Yong who discusses seven possible resonances between "theologizing" and musicking in renewalist/Pentecostal-Charismatic tradition and challenges renewalist theologians to explore this relationship further. Amos Yong, "Conclusion: Improvisation, 
In this chapter I outline a theoretical discussion on the nature and methods of theology in order to argue that Pentecostal praise and worship ${ }^{11}$ is a valid mode of theology - comparable to other theological forms and therefore suitable for theological analysis - and show how an ethnographic approach may help the theologian grapple with this modus theologici in his or her research work. In the first section of the chapter, I argue that the interactive and multimodal nature of theology - as well as the charismatization of contemporary Christianity - requires us to search for new methods in theology, suggesting ethnography as a viable choice. In the second section, I illustrate this perspective through my own research, discussing my methodology and the findings of my study. The reader will be presented with a background to the ritual of praise and worship in CITAM Woodley before I briefly explore the theological meanings that my informants attach to the concept of worship, as well as some of the theological themes that appear in worship songs.

\section{Praise and Worship as a Mode of Theology}

Before proceeding, I want to draw the reader's attention to the difference in academia between normative/constructive theology and analytic theology, with normative theology referring to theological reasoning with a confessional base, while analytic theology works within a critical framework, analyzing Christian faith from a secular starting point. In confessional theological schools, and globally speaking, constructive theology dominates the discipline, while in the Swedish university setting analytic theology is most common.

Indigenization, and Inspiration: Theological Reflections on the Sound and Spirit of Global Renewal" (2015) in Monique Ingalls and Amos Yong, eds. The Spirit of Praise: Music and Worship in Global Pentecostal-Charismatic Christianity (University Park: The Pennsylvania State University Press, 2015), 279-288.

11 In the charismatic idiom praise and worship may refer both to a musical genre (sometimes called just "worship music") and to a related liturgical structure where the church service begins with a continuous string of songs ("worship set") led by band ("worship team"), characterized by a dramaturgic progression from "praise" (communally oriented up-tempo songs) to "worship" (intimate low-tempo songs). See Monique Ingalls, "Introduction: Interconnection, Interface, and Identification in Pentecostal-Charismatic Music and Worship" in The Spirit of Praise: Music and Worship in Global Pentecostal-Charismatic Christianity, edited by Monique Ingalls and Amos Yong (University Park: The Pennsylvania State University Press, 2015), 1-25. In this text the second usage is what interests me, and I will refer to it as the praise and worship ritual or praise and worship interchangeably, while songs sung during that segment of the church service are called worship songs. In addition to this worship in charismatic idiom may also refer to the general idea of honoring God, regardless of the means, see below. 
However, the distinction might not be as sharp as we would like it to be, as analytic theology depends on other people's normative/constructive theologymaking and most constructive theologians work analytically to a large extent. Personally, I try to keep a foot in both camps as I think both approaches are fruitful and can be combined. In this text I am primarily speaking as a Swedish academic theologian analyzing how Pentecostal theology is expressed in praise and worship, but to some extent I am also speaking as a constructive Pentecostal theologian ${ }^{12}$ arguing that praise and worship is a valid mode of theology that say something true of God. Assuming that praise and worship can indeed be counted as a form of theology, what then is theology?

\subsection{The Nature of Theology}

The debate over what theology is - that is, the nature of theology - is a classic one within the theological discipline and can be approached in many ways, resulting in different answers. Within systematic theology the question is often discussed under the label prolegomena or preliminaries, debating whether knowledge of God is even possible and on what grounds. ${ }^{13}$ The evangelical theologian Millard J. Erickson defines theology as:

that discipline which strives to give a coherent statement of the doctrines of the Christian faith, based primarily on the Scriptures, placed in the context of culture in general, worded in a contemporary idiom, and related to issues of life. ${ }^{14}$

To him, the starting-point of theology is the self-revealing God, presupposing both the object of study (God) and the means of knowledge (revelation). As God has made himself known - in Christ, in nature, history, human personality, and in the words and acts preserved in the Bible - knowledge of God is

12 I designate myself a Pentecostal theologian due to my background in, and affiliation with, the Pentecostal movement in Sweden. However, I do not understand the term "Pentecostal" in a narrow sense as someone believing in the "baptism of the Spirit as a second blessing followed by the sign of speaking in tongues," but in a wider sense as someone believing in the triune God and counting on the transformative and regenerative power of the Holy Spirit through the cross and the resurrection of Jesus Christ.

13 Alister E. McGrath Christian Theology: An Introduction (Oxford: Blackwell Publishers, 1997), 152-153. "Theology" comes from the Greek words theos (God) and logos (word), hence "knowledge of God/discourse on God" (ibid., 142).

14 Millard J. Erickson, Christian Theology (Grand Rapids: Baker Books, 1998), 23. 
possible and so also is theology, understood as a worldview or doctrinal system. ${ }^{15}$

Another way to approach the question is a historical one, tracing the different meanings attached to the concept over the centuries. One such attempt has been made by Edward Farley, who says that the term theology is "fundamentally ambiguous"16 as it refers to things of entirely different genres. This ambiguity, he argues, is due to pre-modern understandings of theology as both an actual salvifically oriented knowledge of God (theology as wisdom), and a discipline, a scholarly enterprise (theology as science). When the two ways of understanding theology drifted apart, and yet the same concept continued to be used for both, the present ambiguity of the term arose. ${ }^{17}$

A third perspective is offered by Catholic theologian Robert Schreiter in what he calls "a sociology of theology"18 which divides theology into four different types or styles. These are: (1) theology as variations on sacred text (commentaries, narratives, sermons, etc.); (2) theology as wisdom (the mystical search for knowledge of self and God); (3) theology as sure knowledge (a systematic, philosophical, and critical discipline); and (4) theology as praxis (a dialectical process of reflection and action aimed at social transformation). The strength of Schreiter's model is that it also discusses the cultural and social conditions under which different types of theology thrive and does not judge any of them as being more or less sophisticated or "real" theology. ${ }^{19}$

The authors behind Talking About God in Practice. Theological Action Research and Practical Theology, presents a fourth perspective. They also propose a four-part model, though speak of these as the four voices of theology, implying that theology may take different forms (speak with different voices) within the same cultural and historical context. The four voices they identify are: (1) normative theology (Scriptures, creeds, liturgies, official church teaching); (2) formal theology (academic theology, theology of theologians); (3) espoused theology (theology embedded in a group's articulation of its beliefs); and (4) operant theology (theology embedded within the practices of a group) ${ }^{20}$ This model has much to offer theologians who work with empirical research

\footnotetext{
15 Ibid., 34-35.

16 Edward Farley, "Theologia: The history of a concept" in Readings in Christian Theology, edited by Peter C. Hodgson and Robert H. King (Minneapolis: Fortress Press, 1985), 1.

17 Ibid., 1-3

18 Schreiter, Constructing Local Theologies, 8o.

19 Ibid., 80-93.

20 Helen Cameron et al., Talking About God in Practice. Theological Action Research and Practical Theology (London: scm Press, 2010), 53-56.
} 
methods, as it presents theology as "properly complex,"21 neither discounting any of the four voices nor yet seeing them as interrelated and interdependent. Practice(s) here counts as a form of theology in any setting, not only where it is oriented towards social transformation (theology as praxis in Schreiter's model). This allows us simultaneously to "read theology" in the everyday activities of any faith community, as well as from their official teachings, their sermons, and their narratives, while at the same time acknowledging the academic discipline of theology as something distinct and yet related.

Neither of these models is exhaustive and neither covers everything that theology has been and is understood to be. The point here is rather to show how complex this subject is and that there are good reasons to see theology as more than a critical or intellectual endeavor ${ }^{22}$ although historically it has predominantly been just that.

\subsection{In Search of New Methods in Theology}

In his introduction to Christian theology, Professor Alister McGrath describes the discipline of theology from the Middle Ages to the Enlightenment as an intellectual reflection on the nature, purposes, and activity of (the Christian) God, and a systematic study of Christian doctrine. Later on, theology developed into an academic discipline analyzing religious belief systems more generally, Christian and others. ${ }^{23}$ In both cases, theology was a text-bound activity, done by and for a well-educated male elite - the clergy and academia. The foundational sources for theological reasoning (however their relative importance was debated) were Scripture, tradition, reason/philosophy, and human existential experience. ${ }^{24}$ During the latter part of the 2oth century, liberation theology paved the way for a major shift in how theology is understood, including the experiences of the poor in their socio-political context as a legitimate source of theology and insisting on praxis as both the starting point and the goal of theological reflection. ${ }^{25}$ This gave rise to a whole field of discussion of contextual theology, black theology, and different forms of feminist/womanist theology, and highlighted the situatedness and particularity of all forms of theology. That also led to an opening, at least in theory, for more voices to be

\footnotetext{
$21 \quad$ Ibid., 53.

22 Compare Mika Vähäkangas, this volume, who distinguishes between folk belief, theology, and doctrine, and sees theology as a critical, self-critical, and systematic elaboration of faith content.

23 McGrath, 141-142.

24 Ibid., 181-232.

25 Ibid., $116-118$.
} 
heard in the theological conversation, female voices as well as those of the poor and the oppressed.

In a similar way, I would argue that the current charismatization of Christianity ${ }^{26}$ has the potential to generate a new shift in theology where not only the socio-political context but also the communal-spiritual experience is allowed to count as a valid source for theology-making. This widens the "data" from which we create "theory" in theology to include not only Scripture, tradition, reason, and socio-political contexts, but also the communal life of local churches and the spiritual experience of ordinary believers. Again there is a potential for new voices to be heard in theology as the thoughts, experiences, faith - indeed, the theology - of lay Christians is taken into account. This, however, requires us to use new methods in academic theology, apart from the traditional exegetical, hermeneutical, and philosophical methods. As a matter of fact, it requires theologians to start discussing issues of method, data, and theory in a whole new way, rather than just presuming that we know what we are doing and how to do it. Too much of academic theological research is focused on the hands-on work of analyzing and interpreting specific texts, while not many theologians ask themselves the basic methodological questions of how and why things are done in the way they are.

There are exceptions though. One example is the anthology, Perspectives on Ecclesiology and Ethnography, in which a range of authors discuss and exemplify how ethnographic methods can be used when studying the Christian Church, and how data generated by such research can form the basis of theological reasoning and reflection. Based on the idea of the Church as simultaneously theological and social/cultural they argue that ecclesiology must make use of ethnographic methods in order to speak credibly and justly about it. To do so is a way to take seriously the situatedness of the Church as the body of Christ on earth. ${ }^{27}$ In his introduction Pete Ward says:

The turn toward the ethnographic represents a strategic intervention in Christian theology. Methods of research are never neutral. ... Whatever the disciplinary field and whatever the particular point at issue, the ethnographic 'voice' focuses attention on the lived and the local. ${ }^{28}$

26 Moritz Fischer, “The Spirit Helps Us in Our Weakness': Charismatization of Worldwide Christianity and the Quest for an Appropriate Pneumatology with Focus on the Evangelical Lutheran Church in Tanzania," Journal of Pentecostal Theology 20, no. 1 (2011), 95-121.

27 Pete Ward, "Introduction," in Perspectives on Ecclesiology and Ethnography ed. Pete Ward (Grand Rapids: Eerdmans Publishing Co., 2012), 2-5.

28 Ward, "Introduction," 9. Emphasis added. 
Why would the charismatization of Christianity generate a shift towards studying lived Christianity? Well, to me it seems to be the most viable way forward, given the character of Pentecostal faith. Theology-making within Pentecostalism (understood here in a wide sense, see Anderson ${ }^{29}$ ) has from the very outset been what could be designated as "popular," "non-academic," "oral," or "pietistic" theology. ${ }^{30}$ Since its inception, Pentecostal theology has been expressed in testimonies, rituals, sermons, songs, devotional literature, magazines, TV and radio programs, and in many other ways, but not until quite recently has it also been formulated in academic literature. So if we as researchers want to investigate Pentecostal theology and do justice to it, we need to look at the former sources rather than academic texts, and learn to use methods that are appropriate. Here ethnography helps us focus our attention on the lived and the local and to do so in an academically credible way. The question is whether theologians will be prepared to take up the task and enter into dialogue with the anthropologists and social scientists who so far dominate the field of Pentecostal studies in Africa. I think this is a crucial issue for the future of theology itself, due to the rapid shift of focus within Christianity from the North to the South and from mainline churches to Pentecostal-Charismatic churches. If theology is to be relevant and plausible within the contemporary church (not only as an academic discipline), and if there is to be any connection between the way we think of the church doctrinally and how life in the local church is actually lived, then theologians need to take the challenge of "the ethnographic turn" seriously, as Pete Ward and his colleagues argue. ${ }^{31}$

In my case this means that I take the communal worship service of two specific churches as my starting point for analyzing the theology of worship (operant and/or espoused). For my $\mathrm{PhD}$ project I have observed services and collected lyrics as well as interviewing pastors and worship leaders in order to get close to the meaning and function of praise and worship. But in doing so I have had a distinctly theological interest, wanting to know how theology is created and expressed in and through praise and worship (considered as both songs and as ritual), and how the ritual of praise and worship is motivated theologically by its practitioners. The lived faith (as observed using ethnographic methods) of these two churches in urban Africa thus forms the basis of my

29 Allan Anderson, An Introduction to Pentecostalism. Global Charismatic Christianity (Cambridge: Cambridge University Press, 2004), 9-14.

$30 \quad$ For a discussion of terms see Kenneth J. Archer, The Gospel Revisited. Towards a Pentecostal Theology of Worship and Witness (Eugene: Pickwick Publications, 2011), 5-11.

31 Ward, "Introduction," 4-9. 
theological enterprise. ${ }^{32}$ For this article, however, I have chosen to delimit my analysis to only one of them, CITAM Woodley.

Taking the life of the Church of Christ seriously is, however, not something new in theology. Neither is the use of songs or rituals as a basis for theological reflection. Some of the most important Christological texts - for example, Philippians 2, Hebrew 1, and Revelations 5 - are doxologies that were most probably sung in the early church. No theologian would dream of dismissing them as a basis for theological reflection just because they are songs. The early church was aware of the close connection between worship and theology, as captured in the principle called lex orandi, lex credendi (roughly translated by McGrath as "the way you pray determines what you believe"33). This shows us that the life of the Church and its rituals, including songs, have always been intimately connected to theology. The new element is that we now turn to contemporary churches and contemporary songs instead of the historical or biblical, and that urges us to search for new methods in theology as well as providing material for continuous reflection on the nature of theology itself.

\subsection{Theology as an On-going Process of Interaction}

So far I have briefly introduced the reader to the theological debate concerning the nature of theology and discussed the need for new research methods in order to match developments in the contemporary Church. In this section I outline my own perspective on how constructive theology-making takes place as a creative and relational activity with many outcomes, seeking both to acknowledge the communal-spiritual experiences of believers as valid sources of theology and to delineate theology itself as a multi-modal and interactive process. Readers familiar with evangelical and/or Pentecostal theology will recognize the basic elements of this perspective, although the model itself is my own reasoning. It should be noted that it does not in any way exclude other models presented above, but, rather, seeks to complement them and spur further reflection.

For me it is fruitful to look at constructive theology-making as an ongoing process of interaction between text and context and between relating and reflecting. This process of interaction generates a whole range of different forms or modes of theology, all with their specific emphases, and takes place wherever Christian faith is lived, expressed, and reflected upon.

Illustrated in Figure 8.1, the model looks like this: mentally defined love" for ethnography (compare Joel Robbins, this volume), but at least it is done with the hope of developing my own discipline in the long run. 


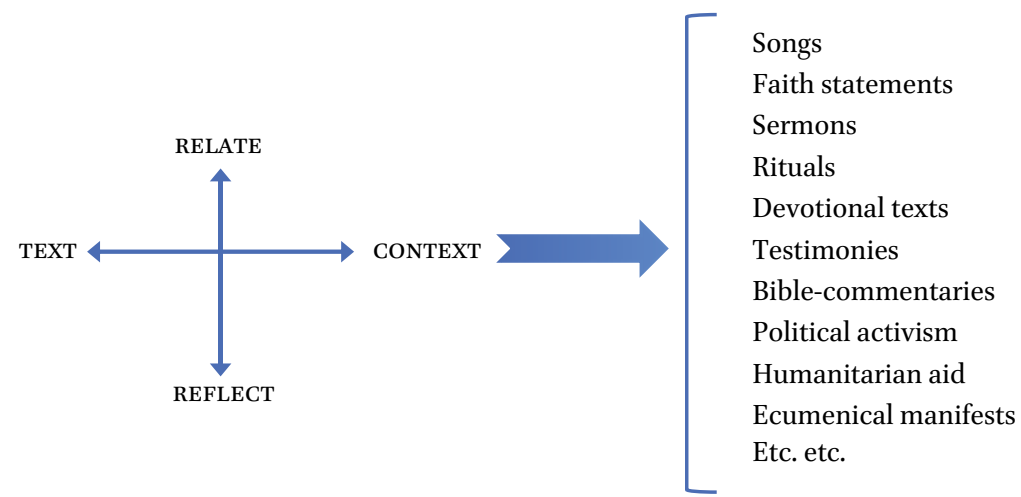

FIGURE 8.1 Theology as process.

The model has two axes and starts with the vertical one, with the selfrevealing God at the top, who is in himself relational and seeks to relate to his creation. He reveals himself to humanity through nature, history, human personality, and Scripture, but most of all through his Son, Jesus Christ. Responding to God's self-revelation we seek God and start to live in a personal relationship with him. Through the Holy Spirit we are born again, filled with his love and power, and by baptism taken into his Church, the Body of Christ. Living now in this new state, we start to reflect on who God is and what implications that has for us as human beings and as an ecclesial community. Then our faith and understanding is deepened and so is our relationship with God and each other. And thus it goes on in a continuous move back and forth between relating and reflecting, and this, I would say, is the embryo of all Christian theology.

More explicit forms of theology arise when the first axis is combined with a second, namely that of text and context. For as God revealed himself to us, $\mathrm{He}$ did so through the Word, Christ, and the written word that centers on him. Therefore words, that is, texts, are central to Christian theology-making, both as sources and as expressions of theology. However, no text can be read and understood apart from its context and no text can be made relevant for new readers unless it also relates to their context. Therefore it is part of theology's task to reflect on the various contexts of biblical texts, as well as on the many texts and contexts of the Church, historical and contemporary. Then a new cycle begins, where the text is understood from its own context as well as from ours and at the same time the text is allowed to speak in and to our context to correct and challenge our way of life.

In my understanding, this ongoing interaction between relating to God and fellow-humans and reflecting on those relationships in the light of both text 
and context generates a whole range of different expressions that may all be seen as valid modes of theology. Examples include philosophical or devotional texts, oral testimonies, songs, sermons, ecumenical manifests, church statutes, ethical guidelines, creeds, catechisms, political activism, humanitarian work, liturgies, and many other forms of expression. While belonging to different genres, they may still be regarded as outcomes of a communal, creative, and constructive theology-making process. Paraphrasing the well-established term loci theologici (theological topics or content categories), I propose that the above examples and many other theological expressions may be viewed as different modi theologici (theological modes) in their own right, enabling us to build a theoretical frame for investigating them as theology (and not, for example, as folk belief or religious practices). This has methodological consequences, for if theology is creatively expressed in many different modes, then theology as a discipline (theological research) must work accordingly, finding the most suitable method to examine the theological mode under study.

\subsection{Praise and Worship as a Mode of Theology-Methodological Challenges}

Coming back to my own focus of research I conclude that the ritual of praise and worship is a modus theologicus comparable to other forms, and therefore suitable for critical theological examination. In fact, my own interest in praise and worship as a field of research began with these sorts of reflections on the nature of theology, coupled with a desire to open it to greater dynamism theoretically and methodologically. When I embarked on my $\mathrm{PhD}$ journey I had for long been frustrated by how little of the lived faith of Pentecostal-Charismatic Christianity is actually spelled out and researched as theology, especially in Sub-Saharan Africa where sociologists and anthropologists are much ahead of theologians in the field. It seemed necessary to find new ways of researching African Pentecostal theology, as so much of it is expressed in genres other than books or even writing. Thinking of the centrality of praise and worship, ${ }^{34}$ as

34 The centrality of worship and music has many times been affirmed by scholars writing about global Pentecostalism; see for example: Paul Alexander, Signs \& Wonders: Why Pentecostalism is the World's Fastest Growing Faith (John Wiley \& Sons, 2009), 17-37, Ogbu Kalu, African Pentecostalism. An Introduction (New York: Oxford University Press, 2008), 121-122 and Donald Miller and Tetsunao Yamamori, Global Pentecostalism. The New Face of Christian Social Engagement (Berkeley: University of California Press, 2007), 23-24, 131141. However, not until very recently has there been a comprehensive introduction to the subject: Monique Ingalls and Amos Yong, eds. The Spirit of Praise: Music and Worship in Global Pentecostal-Charismatic Christianity (University Park: The Pennsylvania State University Press, 2015). 
well as the importance of rituals ${ }^{35}$ for global Pentecostalism in its many forms, this appeared to be a relevant focus of research where an analytic and constructive approach could be combined and an ethnographic method tried. The almost entire lack of qualitative research ${ }^{36}$ on Pentecostal rituals of praise and worship in Eastern Africa ${ }^{37}$ made it all the more relevant. At the same time though, this also meant I had to struggle with methodological issues.

The first problem was educational. As a theologian I was trained in textbased hermeneutics, historical methods, biblical languages, and philosophical reasoning, and I had not had any training at all in fieldwork methods or anything close to qualitative research of an ethnographic type. I had to learn everything from scratch, reading books by DeWalt and DeWalt, ${ }^{38}$ Kvale and Brinkman, ${ }^{39}$ Corrine Glesne ${ }^{40}$ and Karen O'Reilly ${ }^{41}$ among others. I entered a steep learning curve that got even steeper as I came into the field. The second challenge was that of research design and data collection. How does one work as an ethnographic researcher and a theologian at the same time? Is there a specifically theological way to do ethnography? And is that different from how anthropologists do it? I found it hard to give any clear-cut answer to these questions, as anthropologists work in so many ways, while there are very few theologians providing examples. The emerging dialogue between anthropology and theology may hopefully prove helpful in this regard. However, I do think that Vähäkangas is right in that a very open-ended approach is less suitable for a theological study than a more structured one targeting specific questions and seeking out specific people. ${ }^{42}$

35 On the role of rituals in Charismatic Christianity see Martin Lindhardt, "Introduction" (2011), in Practicing the Faith: The Ritual life of Pentecostal-Charismatic Christians by Martin Lindhardt, ed. (New York: Berghahn Books, 2011), 1-29 and Joel Robbins, "The Obvious Aspects of Pentecostalism: Ritual and Pentecostal Globalization" in the same volume.

36 The one notable exception is Jean Kidula's study of Christian music and rituals (including Pentecostal) among the Longooli in Kenya: Jean Kidula, Music in Kenyan Christianity: Longooli Religious Song, (Bloomington: Indiana University Press, 2013).

37 For a discussion of Pentecostalism in this region see: Martina Prosén, "Pentecostalism in Eastern Africa" in Bongmba, Elias. The Routledge Companion to Christianity in Africa, (New York: Routledge, 2016), 297-316.

38 Kathleen M. DeWalt \& Billie R. DeWalt, Participant Observation: A Guide for Fieldworkers (Walnut Creek: AltaMira Press, 2002).

39 Steinar Kvale and Svend Brinkmann Den kvalitativa forskningsintervjun (Lund: Studentlitteratur, 2014).

40 Corrine Glesne, Becoming Qualitative Researchers: An Introduction (Boston: Pearson, 2011).

41 Karen O'Reilly, Ethnographic Methods. (London: Routledge, 2005).

42 Vähäkangas, this volume. 
When I came to the field I had a distinct interest in the theology of praise and worship, and I tried to stay as focused as possible on that interest when designing my project. Due to the complexity of my research object (where worship can be a theological concept, a ritual, and a music genre), I figured that triangulating data would be more effective for analysis than relying on a single source. I also thought that combining information from two different churches within a common social and geographic area would be better than relying on either one of them alone. My fieldwork method thus consisted of a combination of participant observation in church services (including audio and video recordings), the collection of worship songs, semi-structured interviews, and a demographic survey in each church..$^{43}$ My time in the field was very limited, a total of four months divided into three periods, far too brief for an anthropological study but, to my understanding, enough for a theological one.

The third problem was that of analysis: how does one analyze material that is so differentiated, taking its complexity into account and yet retaining one's theological gaze? To be sure the analysis would be colored by the theologian's preference for texts and linguistic and hermeneutical training. At the same time, hopefully, the ethnographic attentiveness to the lived and the local would add a distinctly new and intriguing dimension to it. In the following section I present one of the two selected churches in greater detail and discuss some of my results and the process of analysis.

\section{Praise and Worship in cITAM Woodley}

Before proceeding to a description of the ritual of praise and worship, and discussion of the theology in and of worship, the congregation being studied requires introduction. CITAM Woodley is situated in the Woodley neighborhood in North-Eastern Nairobi, Kenya. The congregation is one of the branches of Christ is the Answer Ministries (CITAM) that is an umbrella body for several assemblies that together form a church. CITAM has a well-defined governance structure, both within the organization as a whole and within each assembly. A bishop functions as the general overseer and each congregation is led by a senior pastor. As weekly attendance amounts to around 30,000, and the number of assemblies to 18 (including one in the US and one in Namibia), ${ }^{44}$ one

43 When referencing the collected data I use the following categories: fieldnotes, observation guides, worship sets, sound recordings, interview transcripts and lyrics, all organized by name and date.

44 http://www.citam.org/, accessed 2017-01-12. 
could almost speak of it as a denomination. ${ }^{45}$ All branches are English-speaking and target the educated middle class and the international community of Nairobi. The mother church of the branches/assemblies within CITAM is the Nairobi Pentecostal Church (NPC), a local church in central Nairobi, now called ciтAм Valley Road. Founded by a missionary from the Pentecostal Assemblies of God in Canada (PAOC) in the 1950s, the church still has a close connection with this denomination, for example in the area of education. ${ }^{46}$ CITAM Woodley is known among the branches for its comparatively young membership and for its vital music department. It is also known for its educational role, starting off as a church for the primary school that shares its premises. ${ }^{47}$ In 2014 the assembly had a weekly attendance of around 5,00o people, including children and youth. ${ }^{48}$

\subsection{Praise and Worship as Part of the Church Ritual}

Sunday services in CiтAM Woodley - and to my knowledge in the other branches as well - all follow the same liturgical pattern, with little variation. Each Sunday they hold three services with a more or less identical program. Looking at it from the outside, the church service appears highly ritualized ${ }^{49}$ although the pastors themselves are a bit hesitant to speak of a fixed liturgy, and underline that the response of the congregation makes the three services very different from each other. ${ }^{50}$

The liturgical pattern is as follows: first there is a time of "praise and worship," which usually takes about $25^{-30}$ minutes (less in some of the other branches). ${ }^{51} \mathrm{~A}$ group of worship leaders, together with the choir and musicians ("the music team"), leads this segment. Then the person hosting the service appears on the stage (referred to as "the altar") to pray for a few minutes, and sometimes this is followed by another worship song. The host then greets the

45 CITAM does not understand itself as a denomination, but one of the pastors says that they are heading in that direction; interview with Pastor Kimiywe 20130114.

46 Interview with Pastor Kimiywe 20130114.

47 Interview with Pastor Grace 20140131.

48 Interview with Pastor Obara 20140321.

49 Compare Roy Rappaport who defines a ritual as: "the performance of more or less invariant sequences of formal acts and utterances not entirely encoded by the performers" in Roy A. Rappaport Ritual and Religion in the Making of Humanity, (Cambridge: Cambridge University Press, 1999), 24. See also Catherine Bell Ritual. Perspectives and Dimensions, (Oxford: Oxford University Press, 1997) and Roland Grimes Beginnings in Ritual Studies, (Columbia: University of South Carolina Press, 1995) for discussions on how to define a ritual/ritual act.

$50 \quad$ Interview with Pastor Obara 20140321. Interview with Pastor Grace 20140131.

51 Interview with Pastor Grace 20140131. 
congregation, welcomes newcomers, and encourages everyone to greet each other. After that there is a section in the program that may include various items depending on the day (for example Holy Communion, baby dedication, testimonies, etc.), followed by information on the screens, and a collection, usually accompanied by playback worship music. Before the sermon begins the congregation is presented with a "special song," typically a text-intensive four-part vocal composition performed by the choir. The sermon, which lasts for about an hour, is followed by a time for intercession called "altar call," where people come up front to be prayed for. This segment may last for two to twenty minutes depending on how long the sermon was and whether it is the first or last service of the day. The first and second service cannot take more than two hours in total, while the third service can go on for another half an hour or more if needed. The choir leaves the stage before the sermon in the first and last services while it sits in for the whole service during the second.

The number of songs in each Sunday service varies between five and eight, and many songs are well known in Evangelical and Charismatic churches around the world. The repertoire includes East-African gospel music, 19th century European hymns (some in Swahili versions), Afro-American spirituals, and contemporary global worship songs. ${ }^{52}$ I only noticed one song that was composed within the CITAM, the rest stem from other sources. The church has a policy on Swahili songs, saying that each Sunday service should include at least one and a maximum of two, as the church targets both the local people and the international community of Nairobi. ${ }^{53}$ In the prayer meeting on Wednesday evenings called "Power House," worship leaders are allowed to include more Swahili songs, something I also observed during my fieldwork.

The worship leaders prepare a document, called a "worship set," listing the songs, including full lyrics, for each Sunday/Wednesday service and put that on Facebook before the Saturday rehearsals. In the worship set there is also information on who will lead the worship, what dress code is expected and, frequently, links to YouTube clips featuring well-known artists singing the chosen songs. ${ }^{54}$ The worship sets are followed rather closely, and in my experience there are only minor differences between what is planned and what is

$5^{2}$ Compare Kidula's description of the development of music within the Nairobi Pentecostal Church. See Jean N. Kidula, "Singing the Lord's Song in the Spirit and with Understanding: The Practice of Nairobi Pentecostal Church." in ed. Monique Ingalls \& Amos Yong, The Spirit of Praise: Music and Worship in Global Pentecostal-Charismatic Christianity. (University Park: The Pennsylvania State University Press, 2015), 133-147.

53 Interview with Pastor Grace 20140131. In my survey I found that nine out of 330 respondents originated outside of Kenya, all of them in other African nations.

See, for example, Worship set, Woodley 20140312 Power House. 
implemented, which indicates how ritualized praise and worship are in this setting. Only in one or two cases did the actual worship service deviate entirely from the worship set.

\subsection{Theological Motivations for Praise and Worship}

Singing and music clearly has a central place in the liturgical life of the church, but how are praise and worship rituals motivated theologically? When I asked my informants, they all started with general discussion about honoring God in every aspect of one's life. This was the most common answer and almost all elaborated on it, church leaders and congregants alike. To them worship cannot be separated from life in Christ; it is basically the same thing. Singing is just one possible expression of worship among many, but the most important form of worship is the personal life of the believer. What counts for these Pentecostals is lived faith, that faith becomes tangible, personal, and all encompassing. As many of them phrased it: worship is a lifestyle. ${ }^{55}$

When specifically asked about theological motivations for the use of music and singing in the church ritual, informants typically referred to the Old Testament liturgy or the psalms of King David, but also to humans' being created musical, and to the preferences of God, saying that He "loves music." ${ }^{56}$ However, the main motivation seems to be that the ritual of praise and worship functions as both sacrificial, giving an offering of songs and self to God, ${ }^{57}$ and sacramental, mediating the presence of God to the congregation in a special way. 58

\subsection{Analyzing Lyrics in Search of Theology}

Theological deliberations surrounding worship are indeed important and could be discussed further, and yet it is not the only way one can approach the theology of worship in this setting. One can also consider the content of worship songs and the patterns that become manifest when lyrics are analyzed

55 Interview with Pastor Grace 20140131; Interview with Pastor Obara 20140321; Interview with Woodley Music team 20140208; Focus Group, Woodley 20140316.

56 Interview with Pastor Obara 20140321.

57 Compare Jon Bialecki, "Between stewardship and sacrifice: agency and economy in a Southern California Charismatic church," Journal of the Royal Anthropological Institute 14, no. 2 (2008), 372-390.

58 See Martina Prosén, "Songs that carry transformation: Pentecostal praise and worship rituals in Nairobi, Kenya," Mission Studies 35, no. 2 (2018), 265-285, where I discuss this further. 
from a theological perspective. ${ }^{59}$ This raises some methodological challenges, as will be discussed below, but first some figures: out of eight ${ }^{60}$ observed services, I collected 54 different songs (listed in worship sets and sung in church), which amounts to an average of 6.75 unique songs sung in each service. Only two songs were sung on more than one occasion, pointing to the high level of planning and organization surrounding the church ritual and CITAM's broad musical repertoire. It does not necessarily imply, however, that these songs are all new to the congregation; my impression was rather the opposite. It seemed like the songs were well known in most cases, either because they were taken from the large ecumenical song tradition with which many congregants are familiar, or because they are often played on Christian radio or distributed via other media. ${ }^{61}$

The sheer volume of songs forced me to choose between selecting just a few for in-depth analysis or taking a helicopter perspective and trying to uncover theological patterns in the whole corpus. Both methods raised questions: in the case of the first, which songs to include or exclude and on what criteria; in the case of the second, whether or not these fifty-four songs of disparate origin could be treated as a corpus representing the theology of the church, and on what grounds. Ultimately I chose the second path as I was interested in the overall theological pattern and thought a broader picture would do more justice to the local theology. The difficulty of choosing which songs to analyze when only two of them were ever repeated (if frequency were to be a deciding factor) also affected the choice. The question remained of whether the selected corpus represented local theology.

As a theologian working ethnographically, my focus is on the lived and the local. My study does not take into account all the worship songs ever sung in CITAM Woodley, but only those that I observed during church services; neither does it take into account the origin and use of these songs in other settings. Instead, I see the church services as the context that defines the texts/lyrics and makes them what they are theologically. In a similar way as one can speak

59 A third obvious way is to analyze the ritual acts; the use of the body, rhythm and sound, material objects, etc., and look at the theological meaning of those; see Tomas Csordas, "Somatic Modes of Attention," Cultural Anthropology 8, no. 2 (1993): 135-146, but that is beyond the scope of this chapter.

6o I count three services on a single Sunday as one, due to their almost identical programs.

61 In Nairobi I heard Christian music played on buses and in shopping malls, and Christian CDs were available on every corner, not to mention the internet. See also Damaris S. Parsitau, "Then Sings My Soul: Gospel Music as Popular Culture in the Spiritual lives of Kenyan Pentecostal/Charismatic Christians," Journal of Religion and Popular Culture 14, no. 1 (2006): 3 . 
of Lucan theology in exegetics, while knowing that much of the Lucan corpus is also present in Matthew and Mark and not original to Luke, one may also speak of a local Pentecostal theology, tentatively treating the collected songs as a textual corpus despite their wide use and disparate origins. The key here is the context and the particularity of ethnographic work. These specific songs have been chosen by this particular church (or rather the worship leaders), during a particular time (winter 2013-2014), to serve a specific purpose (honoring God and mediating his presence to the congregation), and, therefore, they represent the theology of this local Pentecostal congregation, at least in some way, and may be analyzed by me as a researcher. Had I come at a different time, I would surely have collected a different set of songs (for example not so many Christmas hymns), and probably come to slightly different conclusions. However, the church setting and the purpose of the ritual would have stayed the same, and I think it is likely that the overall picture would have been similar.

The analyzing process went as follows: I listened to the sound recordings with the lyrics in front of me and made notes, marking, for example, the names used to address God, the human condition of sin, quotes from the Bible, metaphors for salvation, personal pronoun usage, and so on. Then I made charts displaying the outcome in tables to see the overall pattern. Analysis thus focused on the theological content of songs, and not, for example, on linguistic qualities or stylistic form. This distinctly theological interest is, however, consistent not only with my own research interest, but also with the songs themselves and their doxological, liturgical, and sacramental purposes.

\subsection{Theological Patterns in Worship Songs}

Lastly, let me present some intriguing results of my data analysis. The following description is by no means exhaustive, and yet seeks to point out a few characteristic patterns, based on the whole corpus of worship songs collected in CiTAM Woodley.

The first theological pattern I would like to highlight has to do with how God is addressed, which may also reveal something of how God is conceived. In the 54 songs I found a total of 58 different names and titles used for God. The by far most common expressions are "Jesus" and "Lord." The title "Lord" with its variations (such as The Lord / Bwana / Jehovah / My Lord / etc.) is used in $5^{\circ}$ percent of the songs (27 out of 54), making it the most common expression, closely followed by the name "Jesus" with variations (such as Yesu / King Jesus /Lord Jesus / etc.) that is used in a total of 22 songs. By way of comparison, God is only addressed as "God" (God Almighty / Holy God / The Most High God / etc.) in six songs and as "Father" (Baba / Heavenly Father / etc.) in four. Even more striking is that God is only addressed as "Spirit" (Roho) once, and that is in the 
only song displaying a Trinitarian pattern (speaking of God as Jesus, Father, and Spirit in conjunction). A few other songs mention the Father or the Spirit, while in effect addressing Jesus (for example thanking Him for providing "the Holy Ghost"). Although there are 26 different expressions referring exclusively to Jesus (such as Immanuel / Blessed Son / The Lamb / The Bridegroom / etc.), no song uses the combination "Jesus Christ" and only three songs speak of "Christ," possibly indicating a certain distance from mainline church tradition and a corresponding influence from revivalist Protestantism.

The overall pattern in terms of how God is addressed is strikingly Jesuscentered, leaving almost no room for adoration of God as Father, Spirit, or Triune. This does not imply that Citam Woodley endorses the so-called "Oneness Pentecostalism"; 62 they are clearly Trinitarian in their preaching and statements of faith. ${ }^{63}$ Nevertheless, the emphasis of this Trinitarian theology seems to be rather on the second person of the Trinity, the Son, than on the third person, the Spirit. Thinking of Pentecostalism and how it is usually described by Pentecostals and (social scientific) researchers alike as defined by an emphasis on the Holy Spirit and spiritual gifts, ${ }^{64}$ it is quite astonishing. However, the results of my study point in the same direction as that of church historian Ulrik Josefsson in his study of early Swedish Pentecostals. Placing the Pentecostal movement typologically among pietistic forms of Christianity, he says that even though the doctrine of Spirit Baptism is one key to understanding Pentecostalism, its main content is nevertheless Jesus-centered. ${ }^{65}$ My results are also in line with the arguments put forward by Pentecostal theologian Kenneth Archer, who sees the Fivefold Gospel (Jesus as Savior, Sanctifier, Healer, Spirit Baptizer, and coming King) as "the hub" of Pentecostal theology. ${ }^{66}$ To me

62 Anderson, An Introduction to Pentecostalism, 45-51.

63 http://www.citam.org/ (accessed 2017-01-12).

64 See Allan Anderson's discussion of typological, phenomenological, theological, and historical approaches to the definition of Pentecostalism (all in one way or the other relating to charismatic gifts / Holy Spirit) in "Varieties, Taxonomies, and Definitions" in Studying Global Pentecostalism: Theories and Methods ed. Anderson et al. (Berkeley: University of California Press, 2010), 13-29.

65 "Även om en av nycklarna till att förstå pentekostalismen ligger i läran om andedopet, är det bärande innehållet Jesuscentrerat. Det är en kristendomstyp som är tydligt präglad av den pietistiska fokuseringen på Jesus." Josefsson, Liv och över nog, ${ }^{11}$.

66 Archer, The Gospel Revisited, 14-15. Archer builds on and expands the arguments put forward by Donald Dayton and Ted Peters. See also Amos Yong, In the Days of Caesar: Pentecostalism and Political Theology (Grand Rapids: Wm. B. Eerdmans Publishing Co., 2010), 95-98, who uses the Fivefold Gospel to structure his discussion on Pentecostalism and political theology, arguing that it may serve as a framework that both preserves a distinctly Pentecostal theological self-understanding and honors the pluralistic impulses embedded in Pentecostal experience. 
it indicates a close theological link between this urban Kenyan church and classical Pentecostalism in the West, as well as with earlier revivalist movements such as Methodism and Baptism. ${ }^{67}$ The link is primarily theological, although diachronic and synchronic links to the Pentecostal Assemblies of God Canada (PAOC) certainly exist as well. Partly it is a matter of perspective. If Pentecostal faith is compared to other (revivalist) Protestant traditions, its pneumatology stands out as specific and defining. While if Pentecostal faith is measured by what characterizes it - rather than by what distinguishes it - then Christology certainly qualifies as the defining feature, judging from my data. It may also be a matter of how to understand "Spirit Baptism" or "life in the Spirit" theologically. Often this is understood as part of the pneumatology of Pentecostal theology, that is, the doctrine of the third person, while it may just as well be understood as part of its soteriology or even its Christology. What I mean is that Pentecostal doctrines concerning Spirit Baptism and spiritual gifts have to do just as much with an understanding of what salvation is (life in the Spirit / life with Jesus) and who the Son is (Spirit-giver), as they have to do with how the Spirit per se is perceived. In fact, discussions of the nature of the Spirit (indeed of the nature of God) are rather rare even in academic forms of Pentecostal theology, ${ }^{68}$ while discussions of Spirit Baptism and spiritual gifts abound. ${ }^{69}$

Other patterns that stand out clearly from my data are: (1) a personal approach in the communication between God and human (for example the majority of songs use first and second person pronouns in relating to God:I-You or We-You); (2) an emphasis on God / Jesus as unique in nature, power, and position (for example, many songs speak of God / Jesus as "the only one" or "above everything"); (3) a marked dependency on biblical language (for example, many of the metaphors are taken from the Bible and several songs are Scripture verses set to music); and (4) a richness in liturgical functions or genres

67 The link between classical Pentecostalism and 18th-century revivalism has been noted by several scholars, for example Walter J. Hollenweger, Pentecostalism: origins and developments worldwide (Peabody, MA: Hendrickson Publishers, 1997); Donald Dayton, Theological Roots of Pentecostalism (Peabody, MA: Hendrickson, 1987); David Bundy, Visions of Apostolic Mission: Scandinavian Pentecostal Mission to 1935 (Uppsala: Acta Universitatis Upsaliensis, 2009).

68 But see Amos Yong, Spirit of Love: A Trinitarian Theology of Grace (Waco: Baylor University Press, 2012).

69 For example, James D.G. Dunn Baptism in the Holy Spirit: A Re-examination of the New Testament Teaching on the Gift of the Spirit in relation to Pentecostalism today (Philadelphia: SCм Press Ltd, 2010); Max Turner, The Holy Spirit and Spiritual Gifts: In the New Testament church and today (Peabody, MA: Hendrickson Publishers, 1996); Frank Macchia, Baptized in the Spirit: A Global Pentecostal Theology (Grand Rapids: Zondervan, 2006). 
(from doxologies and songs of thanksgiving to proclamations, testimonies, and personal prayers).

From this brief sketch one may conclude that there is a clear focus on Christology in praise and worship songs, declaring and proclaiming Christ as unique Lord and Savior. Perhaps this is not very surprising given the centrality of the Fivefold Gospel in Pentecostal theology, although I was not prepared for the high degree of uniformity. There is also a clear focus on the relationship between God/Christ and the believer(s) in these songs, one that has a bearing on ecclesiology, missiology, and soteriology, and reflects the theological understanding of praise and worship as mediating the relationship between believer and God. That the Holy Spirit is almost entirely absent from praise and worship songs is interesting and shows that we must look beyond a narrow understanding of Pentecostal theology as defined by pneumatology. This result can be seen as a direct outcome of using an ethnographic method in theological research, as most literature on Pentecostalism would lead us in a different direction.

In this chapter I have sought to present ethnography as a fruitful partner to theology in the study of the lived faith of African Pentecostal believers. Through a theoretical discussion on the nature and methods of theology, as well as a presentation of my own research and some of its challenges, I have tried to show how an ethnographic approach offers a different perspective and provides potentially different insights than an entirely text-based theological approach.

The first section of the chapter argued that the interactive and multi-modal nature of theology as well as the charismatization of contemporary Christianity requires theologians to search for new research methods, in addition to those traditionally used. Ethnography was presented as a viable choice, as it allows us to grapple with the lived and the local in a scientifically credible way. This part also proposed that the ritual of praise and worship can be seen as a modus theologicus, among other things, and some of the methodological challenges of doing so were discussed. In the second part I began by presenting a background to CITAM Woodley, in Nairobi, situating the place of praise and worship within their church ritual, before proceeding to an analysis of the theological motivations of worship and theological patterns in worship songs. The results of the latter analysis show that it may be time to reconsider an emphasis on the Holy Spirit or spiritual gifts as the principal defining feature of Pentecostal faith, and 
start exploring Christology as the central hub of Pentecostal theology. At a minimum the results illustrate how an ethnographic approach may help the theologian gain new knowledge of Pentecostal-Charismatic Christianity in Africa, based on the lived faith of a local church.

\section{References}

Albrecht, Daniel. Rites of the Spirit: A ritual approach to Pentecostal/Charismatic Spirituality. Sheffield: Sheffield Academic Press, 1999.

Alexander, Paul. Signs \& Wonders: Why Pentecostalism is the World's Fastest Growing Faith. San Francisco: Jossey-Bass, 2009.

Anderson, Allan. An Introduction to Pentecostalism. Global Charismatic Christianity. Cambridge: Cambridge University Press, 2004.

Anderson, Allan. "Varieties, Taxonomies, and Definitions." In Studying Global Pentecostalism: Theories and Methods, edited by Allan Anderson, Michael, Bergunder, André Droogers and Cornelis Van Der Laan, 13-29. Berkeley: University of California Press, 2010.

Archer, Kenneth J. The Gospel Revisited. Towards a Pentecostal Theology of Worship and Witness. Eugene: Pickwick Publications, 2011.

Bell, Catherine. Ritual: Perspectives and Dimensions. Oxford: Oxford University Press, 1997 .

Bialecki, Jon. "Between stewardship and sacrifice: agency and economy in a Southern California Charismatic church." Journal of the Royal Anthropological Institute 14, no. 2 (2008): 372-390.

Bundy, David. Visions of Apostolic Mission: Scandinavian Pentecostal Mission to 1935. Uppsala: Acta Universitatis Upsaliensis, 2009.

Csordas, Tomas. "Somatic Modes of Attention." in Cultural Anthropology 8, no. 2 (1993): $135^{-146 .}$

Dayton, Donald. Theological Roots of Pentecostalism. Peabody, MA: Hendrickson, 1987.

DeWalt, Kathleen M. and Billie R. DeWalt. Participant Observation: A Guide for Fieldworkers. Walnut Creek: AltaMira Press, 2002.

Dunn, James, D.G. Baptism in the Holy Spirit: A Re-examination of the New Testament. Teaching on the Gift of the Spirit in relation to Pentecostalism today. Philadelphia: sCM Press Ltd, 2010.

Fiddes, Paul. "Ecclesiology and Ethnography: Two Disciplines, Two Worlds?" in Perspectives on Ecclesiology and Ethnography, edited by Pete Ward, 13-35. Grand Rapids: Eerdmans Publishing Co., 2012.

Fischer, Moritz. "The Spirit Helps Us in Our Weakness': Charismatization of Worldwide Christianity and the Quest for an Appropriate Pneumatology with Focus on 
the Evangelical Lutheran Church in Tanzania." Journal of Pentecostal Theology 20, no. 1 (2011): 95-121.

Glesne, Corrine. Becoming Qualitative Researchers: An Introduction. Boston: Pearson, 2011.

Grimes, Ronald. Beginnings in Ritual Studies. Columbia: University of South Carolina Press, 1995 .

Hollenweger, Walter J. Pentecostalism: origins and developments worldwide. Peabody, MA: Hendrickson Publishers, 1997.

Ingalls, Monique M. and Yong, Amos, eds. The Spirit of Praise: Music and Worship in Global Pentecostal-Charismatic Christianity. University Park: The Pennsylvania State University Press, 2015.

Ingalls, Monique M. "Introduction: Interconnection, Interface, and Identification in Pentecostal-Charismatic Music and Worship." in The Spirit of Praise:Music and Worship in Global Pentecostal-Charismatic Christianity, edited by Monique M. Ingalls and Amos Yong, 1-25. University Park: The Pennsylvania State University Press, 2015 .

Josefsson, Ulrik. Liv och över nog: Den tidiga pingströrelsens spiritualitet. Skellefteå: Artos \& Norma Bokförlag, 2005.

Kalu, Ogbu. African Pentecostalism. An Introduction. New York: Oxford University Press, 2008.

Kidula, Jean, N. Music in Kenyan Christianity: Longooli Religious Song. Bloomington: Indiana University Press, 2013.

Kidula, Jean, N. "Singing the Lord's Song in the Spirit and with Understanding: The Practice of Nairobi Pentecostal Church." In The Spirit of Praise: Music and Worship in Global Pentecostal-Charismatic Christianity, edited by Monique Ingalls and Amos Yong, 133-147. University Park: The Pennsylvania State University Press, 2015.

Kvale, Steinar and Brinkmann, Svend. Den kvalitativa forskningsintervjun. Lund: Studentlitteratur, 2014.

Land, Steven J. Pentecostal Spirituality. A Passion for the Kingdom. Cleveland: CPT Press, 2010.

Lindhardt, Martin, ed. Practicing the Faith. The Ritual life of Pentecostal-Charismatic Christians. New York: Berghahn Books, 2011.

Macchia, Frank. Baptized in the Spirit: A Global Pentecostal Theology. Grand Rapids: Zondervan, 2006.

Martin, Lee Roy, ed. Toward a Pentecostal Theology of Worship. Cleveland: CPT Press, 2016.

McGrath, Alister E. Christian Theology. An Introduction. Oxford: Blackwell Publishers, 1997.

Miller, Donald, E. and Tetsunao Yamamori. Global Pentecostalism. The New Face of Christian Social Engagement. Berkeley: University of California Press, 2007. 
O’Reilly, Karen. Ethnographic Methods. London: Routledge, 2005.

Parsitau, Damaris S. "Then Sings My Soul: Gospel Music as Popular Culture in the Spiritual lives of Kenyan Pentecostal/Charismatic Christians." Journal of Religion and Popular Culture 14, no. 1 (2006): 3 .

Prosén, Martina. "Pentecostalism in Eastern Africa." In The Routledge Companion to Christianity in Africa, edited by Elias Bongmba, 297-316. New York: Routledge, 2016.

Prosén, Martina. "Songs that carry transformation: Pentecostal praise and worship rituals in Nairobi, Kenya." Mission Studies 35, no. 2 (2018): 265-285.

Rappaport, Roy. Ritual and Religion in the Making of Humanity. Cambridge: Cambridge Univeristy Press, 1999.

Robbins, Joel. "The Obvious Aspects of Pentecostalism: Ritual and Pentecostal Globalization." In Practicing the Faith. The Ritual life of Pentecostal-Charismatic Christians, edited by Martin Lindhardt, 49-67. New York: Berghahn Books, 2011.

Schreiter, Robert. Constructing Local Theologies. Maryknoll: Orbis Books, 1985.

Turner, Max. The Holy Spirit and Spiritual Gifts: In the New Testament church and today. Peabody, MA: Hendrickson Publishers, 1996.

Ward, Pete. "Introduction." In Perspectives on Ecclesiology and Ethnography, edited by Pete Ward, 1-10. Grand Rapids: Eerdmans Publishing Co., 2012.

Yong, Amos. In the Days of Caesar: Pentecostalism and Political Theology. Grand Rapids: Wm. B. Eerdmans Publishing Co., 2010.

Yong, Amos. Spirit of Love: A Trinitarian Theology of Grace. Waco: Baylor University Press, 2012.

Yong, Amos. "Conclusion: Improvisation, Indigenization, and Inspiration: Theological Reflections on the Sound and Spirit of Global Renewal." In The Spirit of Praise:Music and Worship in Global Pentecostal-Charismatic Christianity, edited by Monique Ingalls and Amos Yong, 279-288. University Park: The Pennsylvania State University Press, 2015. 